\title{
Rhizobium huautlense sp. nov., a symbiont of Sesbania herbacea that has a close phylogenetic relationship with Rhizobium galegae
}

\author{
E. T. Wang, ${ }^{1}$ P. van Berkum, ${ }^{2}$ D. Beyene, ${ }^{3}$ X. H. Sui, ${ }^{4}$ O. Dorado, ${ }^{5}$ \\ W. X. Chen ${ }^{4}$ and E. Martínez-Romero ${ }^{1}$
}

1 Departamento de Genética Molecular, Centro de Investigación sobre Fijación de Nitrógeno, Apdo Postal 565-A, Universidad Nacional Autónoma de México, Cuernavaca, Morelos, Mexico

2 Soybean and Alfalfa Research Laboratory, Agricutural Research Service, US Department of Agriculture, Beltsville, MD 20705, USA

3 College of Agriculture and Natural Resources, The Department of Natural Resource Sciences and Landscape Architecture, University of Maryland, College Park, MD 20742, USA

4 Department of Microbiology, College of Biology, Beijing Agricultural University, Beijing 100094, People's Republic of China

5 CIEH, Universidad Autónoma del Estado de Morelos, Cuernavaca, Morelos, México
Author for correspondence: E. Martínez-Romero. Tel: +5273131697. Fax: +5273175581 e-mail: emartine@cifn.unam.mx

The nitrogen-fixing rhizobial symbionts of Sesbania herbacea growing in the nature reserve at the Sierra de Huautla, Mexico, were isolated and characterized. All 104 isolates together with the type strain for Rhizobium galegae, HAMBI 540', had similar 165 rRNA genes as revealed by PCR-RFLP analysis. Similarity in the sequences of the 165 rRNA genes placed the isolates on a phylogenetic branch shared with $R$. galegae. Among 66 randomly selected isolates, three closely related electrophoretic alloenzyme types (ETs) were identified, which were distinct from 10 ETs distinguished among 23 strains of $R$. galegae. A new species Rhizobium huautlense, represented by the Sesbania isolate $\mathrm{SO2}^{\mathrm{T}}$, is proposed based upon low estimates of DNA relatedness between our chosen type strain and the type strains for the other species, the dissimilarity of the nucleotide sequence of the 165 rRNA genes, and their distinct ETs compared with $R$. galegae. The description of $R$. huautlense is significant because in the reconstruction of the phylogeny of $R$. huautlense there was a shift in the node of the branch of Agrobacterium vitis relative to that of $R$. galegae. The revised phylogenetic tree would tend to indicate common ancestry between $R$. galegae and Rhizobium leguminosarum.

Keywords: Rhizobium huautlense sp. nov., symbionts, Sesbania herbacea, nitrogen fixers

\section{INTRODUCTION}

There are 70 species within the legume genus Sesbania, which are widespread in the warmer latitudes of both hemispheres of the world (1). Many species are annual or short-lived perennials, which because of their fast growth may be useful to agriculture as green manure

Abbreviations: $E T$, electrophoretic type; $I_{A}$ index of association; MLEE, multilocus enzyme electrophoresis.

The GenBank accession numbers for the 16S rRNA gene sequences of strains $\mathrm{SO2}^{\top}$ and $59 \mathrm{~A} 2$ are AF025852 and AF025853, respectively. or fallow crops $(1,25)$. Besides biomass production, selected species also are useful to control soil erosion, as windbreaks, live fences and as shade in coffee and tea plantations. Several species have fibre that is useful for production of rope, fishing nets and paper. Leaves may be a source of ascorbic acid, diuretics and laxatives.

Since Sesbania species are leguminous plants they are able to form beneficial nitrogen-fixing symbioses with soil bacteria belonging to the family Rhizobiaceae. A symbiosis is evident from the presence of hypertrophies or nodules on the roots of the host plant. In addition to 
Table 1. Isolates and strains used in this study and some of their characteristics

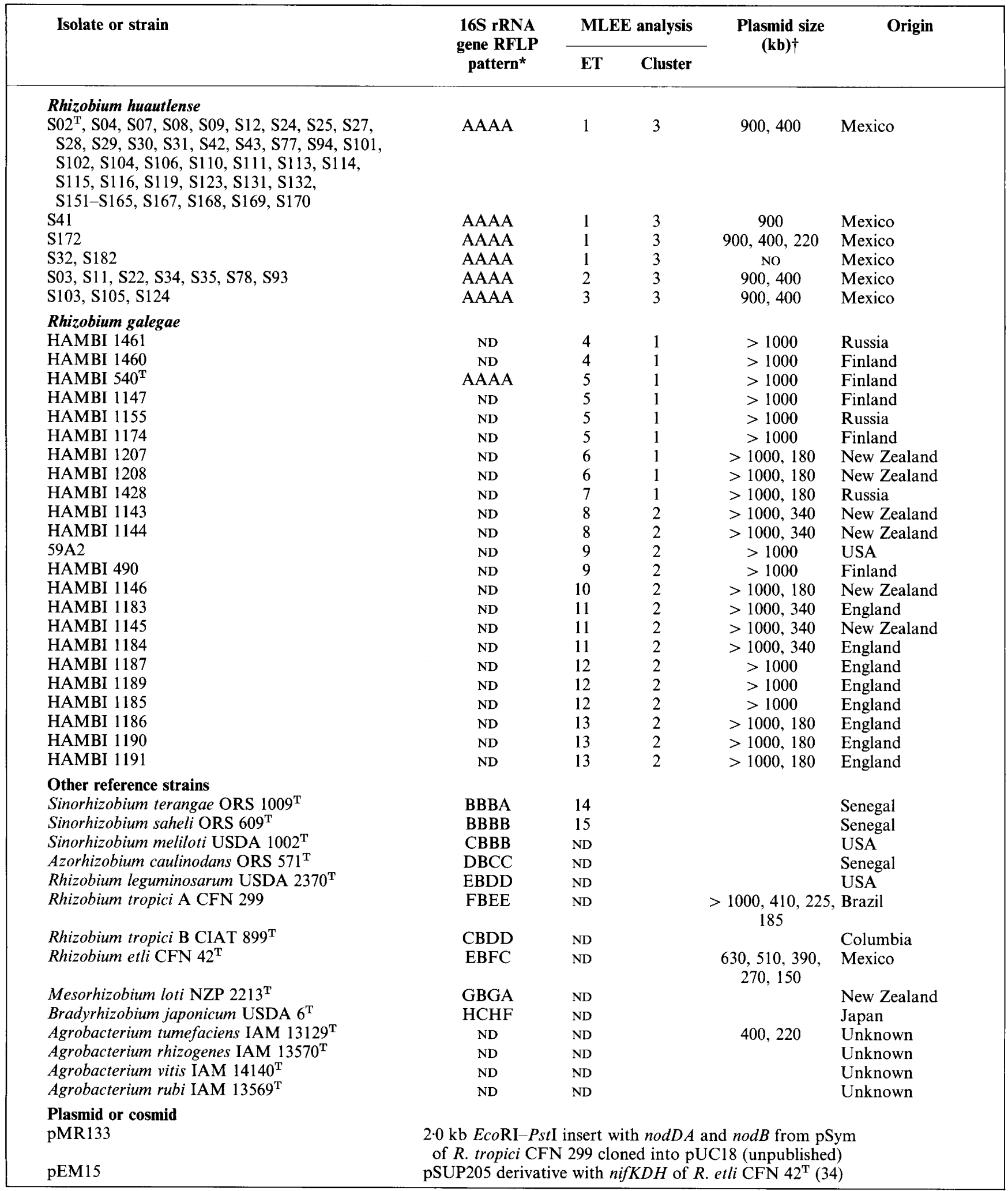

ND, Not detected; No, not observed.

* Four letters were arbitrarily assigned to represent specific fingerprint patterns of $16 \mathrm{~S}$ rDNA RFLP digested with restriction endonuclease MspI, Hinf1, HhaI and Sau3AI, respectively.

$\dagger$ Molecular sizes of plasmids were estimated from their mobilities in $0.7 \%$ agarose gels and the plasmids of $R$. etli $\mathrm{CFN}_{42}{ }^{\mathrm{T}}$ were used as standards. The standard deviation was $6 \mathrm{~kb}$. Strains used for identification of symbiotic plasmids were S02 $2^{\mathrm{T}}, \mathrm{S} 94, \mathrm{~S} 03, \mathrm{~S} 11, \mathrm{~S} 103, \mathrm{~S} 124$ and HAMBI $540^{\mathrm{T}}$. 
root nodules, Sesbania rostrata forms stem nodules (13), which has been explored for determining the potential of using this plant as a green manure crop in the cultivation of rice $(3,19)$.

The bacterial symbionts of legumes are highly diverse and are classified within the $\alpha$-Proteobacteria. Several fundamental morphological and physiological characters separate Rhizobium and Bradyrhizobium (22), and their classification as separate genera is indisputable (16). Similarly, the stem-nodulating symbiont of Sesbania rostrata, Azorhizobium caulinodans, is distinct from the genera Rhizobium and Bradyrhizobium (15). Within the group which was classified as Rhizobium, three separate genera, Rhizobium (18), Sinorhizobium $(8,11)$ and Mesorhizobium (21), are now recognized.

Positive nodulation scores have been reported for 27 of the 70 species of Sesbania (10), but very few of these rhizobial isolates have undergone extensive analysis to determine their genetic relationships within the $\alpha$ Proteobacteria. The most widely known symbiont is Azorhizobium caulinodans, which forms stem and root nodules on Sesbania rostrata (13) and is distinguishable by its ability to grow in pure culture on $\mathrm{N}_{2}$ as sole nitrogen source (14). Although Azorhizobium caulinodans was predominant among the 191 isolations made in Senegal and the Philippines, an additional genomic species within this genus was discovered and a small proportion were indicated to belong to the genus Rhizobium (44). Subsequently, several Sesbania species growing in Senegal, including Sesbania rostrata, were reported to form symbioses with two newly described species within the genus Sinorhizobium, and two isolates from Sesbania marginata that originate from Brazil were classified within the genus Rhizobium (11). However, reconstruction of the phylogeny using 16S rRNA gene sequences of the Sesbania isolates within the genus Rhizobium were not reported. The reported phylogeny of isolates from Sesbania aculeata, originating from Japan (46) and from India (42), indicated a close affinity with $R$. galegae (28).

The molecular evolutionary relationships of bacterial symbionts isolated from the nodules of Sesbania species growing in the North American continent have not been reported. We selected Sesbania herbacea, native to Mexico and the Southern USA, growing in the undisturbed nature reserve at the Sierra de Huautla, Mexico, to avoid the possibility of isolating rhizobial symbionts which became established because of legume inoculation practices.

Our objective was to isolate Sesbania symbionts that are native to the North American continent, determine their genetic diversity and phylogenetic relationships within the $\alpha$-Proteobacteria.

\section{METHODS}

Reference strains, isolations and nodulation assays. Reference strains and isolates used in genetic analyses are shown in Table 1. All the isolates from Sesbania herbacea originated from root nodules which were collected during August and October 1996 from about 20 plants growing in flooded areas at the Sierra de Huautla in Morelos, mountains which have a typical tropical climate in the middle part of Mexico. These plants were collected from two sites, a brook and a lake which are $1 \mathrm{~km}$ from each other and are separated by the mountains. Isolates $\mathrm{S} 02^{\mathrm{T}}-\mathrm{S} 43$ were from the same plant collected from the brook and others were from both of the sites and from different plants. Isolations were made according to the methods described by Vincent (56) using PY (38) as growth medium. Plates were incubated aerobically for $3 \mathrm{~d}$ at $28^{\circ} \mathrm{C}$ and the isolates were purified by streaking single colonies on fresh PY plates. Each isolate was verified as a symbiont of Sesbania herbacea by plant test using the method of Vincent (56). Seeds were surface sterilized with conc. $\mathrm{H}_{2} \mathrm{SO}_{4}$ for 20 min, or scarified with fine sandpaper before they were surface-sterilized with a $1 \%$ $(\mathrm{w} / \mathrm{v})$ solution of $\mathrm{NaOCl}$. Treated seeds were germinated on the surface of $0.75 \%$ water-agar and after germination were sown in plastic cups filled with vermiculite moistened with the $\mathrm{N}$-free nutrition solution described previously (53). Cultures grown overnight in PY broth were used to inoculate the seedlings which were grown for 4 weeks under natural sunlight before the ability of each culture to nodulate the trap host was scored. A Leonard jar assembly (27) was used to determine the ability of $\mathrm{S} 02^{\mathrm{T}}$ and HAMBI $540^{\mathrm{T}}$ to nodulate Galega orientalis, Glycine max, Macroptilium atropurpureum, Medicago sativa, Leucaena leucocephala, Pisum sativum, Phaseolus vulgaris, Sesbania rostrata, Sesbania herbacea, Trifolium repens and Vigna unguiculata. These tests were done in duplicate and results were compared to plants which were not inoculated.

PCR-RFLP analysis and the determination of nucleotide sequences of the $16 \mathrm{~S}$ rRNA genes. Techniques described previously (54) were used for cell lysis to extract the DNA of each culture for PCR analysis and the generation of the $16 \mathrm{~S}$ rRNA gene fragments (approx. $1500 \mathrm{bp}$ ) by PCR using primers $\mathrm{fD} 1$ and $\mathrm{rD} 1$ corresponding to positions 8-27 and 1524-1540, respectively, of the Escherichia coli 16 S rRNA gene (58). For sequencing analysis template DNA for the PCR reaction was prepared from $50 \mathrm{ml}$ MAG (53) grown cells according to the protocol of Navarro et al. (36). The presence of amplification products in the PCR reactions was confirmed by horizontal agarose gel electrophoresis of $10 \mu \mathrm{l}$ subsamples. Subsequently, $5 \mathrm{U}$ each of $H$ haI, HinfI, $M s p I$ or Sau3AI were used to digest 10-15 $\mu$ l subsamples of the PCR reactions (26). Restriction fragment lengths of the different 16S rRNA gene products were determined by their separation in $3 \%$ agarose gels (26). Full length sequences of the $16 \mathrm{~S}$ rRNA genes of strains S02 ${ }^{\mathrm{T}}$ and $59 \mathrm{~A} 2$ were determined from purified PCR products as described previously (53).

Analysis of the sequence data. The sequences were aligned using the PILEUP program in the Wisconsin package of the Genetics Computer Group (Madison, WI, USA). Aligned sequences were analysed using the DNADIST and the NEIGHBOR programs of the software package PHYLIP version $3.5 \mathrm{c}$ (17) and trees were constructed using RETREE and DRAWTREE. Additional analyses were made using the Molecular Evolutionary Genetics Analysis (MEGA) package version 1.01 (24) to derive the nucleotide sequence similarities of the smallsubunit rRNA genes and to investigate how tree topology was affected by increasing the number of sequences in the analysis. 
Multilocus enzyme electrophoresis (MLEE). Culture extracts for MLEE analysis were prepared according to the procedure of Caballero-Mellado \& Martínez-Romero (7) from $40 \mathrm{ml}$ PY broth cultures grown overnight at $28^{\circ} \mathrm{C}$. The extracts were stored at $-20^{\circ} \mathrm{C}$.

Starch-gel electrophoresis and the selective staining for the 12 metabolic enzymes listed in the legend to Table 2 were according to the procedures described by Selander et al. (48). Relative electrophoretic mobilities of each of the enzymes were determined on three separate occasions. Distinctive mobility variants (electromorphs) of each enzyme, numbered in order of decreasing anodal mobility, were equated with alleles at the corresponding structural gene locus. Allele profiles or electrophoretic types (ETs) were equated with multilocus genotypes. The genetic distance between pairs of ETs was estimated as the proportion of loci at which dissimilar alleles (mismatches) occurred. Clustering of ETs from a matrix of pairwise genetic distances was by the method described by Nei \& Li (37). Genetic diversity $(h)$ at an enzyme locus was calculated as described by Selander et al. (48) $h=\left[1-\Sigma x_{i}^{2}\right][n /(n-1)]$, where $x_{i}$ is the frequency of the $i$ th allele at the locus and $n$ is the number of ETs in the population. The extent of linkage disequilibrium (nonrandom combinations of alleles) among ETs was estimated by comparing observed and expected moments of allelic mismatch frequency distributions (59). An index of association' or $I_{\mathrm{A}}$, originally described by Brown et al. (6), was used to demonstrate a non-random association of alleles. Equations for the calculation of $I_{\mathrm{A}}$ and its associated error variance are described by Maynard Smith et al. (32). Programs for the analysis of genetic diversity, ET clustering and linkage disequilibrium were written by $\mathbf{T}$. S. Whittam (Pennsylvania State University). A Monte Carlo procedure with 10000 iterations as described by Souza et al. (51) was also used to estimate the extent of linkage disequilibrium.

Determination of DNA base composition and DNA-DNA hybridization analysis. Cultures were grown in $5.0 \mathrm{ml}$ PY broth for $12 \mathrm{~h}$ at $28^{\circ} \mathrm{C}$ and were centrifuged at $12000 \mathrm{~g}$ for DNA preparation by using a DNA/RNA isolation kit (USB) as described by Chirgwin et al. (9). These samples were used to estimate DNA $\mathrm{G}+\mathrm{C}$ content $\left(T_{m}\right)$ by the method of De Ley (12) and to estimate DNA homologies by using the filter method as described by van Berkum et al. (54). Cultures grown in $50 \mathrm{ml} \mathrm{MAG} \mathrm{(53)} \mathrm{were} \mathrm{used} \mathrm{to}$ prepare DNA (36) for estimation of DNA homology by using the hydroxyapatite batch procedure to separate singleand double-stranded DNA $(4,5)$. The DNA concentrations in samples prepared by either procedure were determined spectrophotometrically by absorbance at $260 \mathrm{~nm}$.

Determination of cellular plasmid content and identification of symbiotic plasmids. The plasmid contents of 66 isolates from Sesbania herbacea and 24 strains of $R$. galegae were visualized by using a modified Eckhardt procedure (20). Plasmid mobilities were determined in $0.7 \%$ agarose gels using plasmids of $R$. etli CFN $42^{\mathrm{T}}$ (45) and of $R$. tropici CFN $299(19,30)$ as reference molecular size markers. The approximate molecular sizes of plasmids were estimated from the gels by using the computer program Seqaid II version $3.5(43)$. Symbiotic plasmids were identified by Southern hybridization analysis using as probes a $2.0 \mathrm{~kb}$ $E c o$ RI-Pst I fragment containing $\operatorname{nod} D A$ and $\operatorname{nod} B$ of $R$. tropici CFN 299 cloned in pUC18 and a $5 \cdot 1 \mathrm{~kb}$ Bam HI restriction fragment containing nifHDK of $R$. etli $\mathrm{CFN} 42^{\mathrm{T}}$
(34). The type strain of $R$. etli (47), CFN $42^{\mathrm{T}}$ (45), and the type A strain of $R$. tropici (31), CFN $299(19,30)$, were used as positive controls.

Phenotypic characterization. The phenotypic characters of 15 isolates from Sesbania herbacea and nine strains of $R$. galegae were determined. The strains and isolates were selected according to their position in the clustering analysis of the MLEE data and according to their plasmid content. With the exception for the determination of growth in LB broth the phenotypic characters were examined by growth on solid media in Petri plates. Each Petri plate was used to determine the characters of six cultures and each character was examined in duplicate. Cultures were scored for growth after incubating the Petri plates for $4 \mathrm{~d}$ at $28^{\circ} \mathrm{C}$. Intrinsic antibiotic resistance was determined on PY medium amended with filter-sterilized solutions of the following antibiotics (final concns): 5, 50 and $100 \mu \mathrm{g}$ ampicillin $\mathrm{ml}^{-1}$; $5,50,100$ and $300 \mu \mathrm{g}$ chloromycin $\mathrm{ml}^{-1} ; 5,50,100$ and $300 \mu \mathrm{g}$ erythromycin $\mathrm{ml}^{-1} ; 5,50,100$ and $300 \mu \mathrm{g}$ gentamicin $\mathrm{ml}^{-1} ; 5,50$ and $100 \mu \mathrm{g} \mathrm{kanamycin} \mathrm{ml}^{-1} ; 5,50,100$ and $300 \mu \mathrm{g}$ lincomycin $\mathrm{ml}^{-1} ; 5,50,100$ and $300 \mu \mathrm{g}$ neomycin $\mathrm{ml}^{-1} ; 5$ and $50 \mu \mathrm{g}$ streptomycin $\mathrm{ml}^{-1}$; and $5,50,100$ and $300 \mu \mathrm{g}$ tetracycline $\mathrm{ml}^{-1}$. A basal medium described by Novikova et al. (39), supplemented with filter-sterilized solutions of pyridoxine and thiamin at final concentrations of $0.025 \mathrm{mg} \mathrm{ml}^{-1}$ according to Oyaizu et al. (41), was used to determine carbon and nitrogen substrate utilization. Bromothymol blue at $0.0025 \%(\mathrm{w} / \mathrm{v})$ was added as $\mathrm{pH}$ indicator. Filter sterilized carbon substrates were added at a final concentration of $0.1 \%(\mathrm{w} / \mathrm{v})$ and included acetate, adonitol, Darabinose, citrate, dulcitol, D-fructose, fumarate, D-galactose, D-gluconate, D-glucose, meso-inositol, lactate, lactose, DL-malate, melibiose, maltose, propionate, D-raffinose, rhamnose, D-sorbitol, succinate, sucrose and D-xylose. Mannitol was used as positive control, and no addition of carbon substrate was used as a negative control. The appearance of single colonies and production of acid or alkaline were recorded. The same basal medium was used to determine utilization of adenine, $\mathrm{L}$-arginine, $\mathrm{L}$-aspartic acid, anthranilic acid, L-cystine, -fluoro-DL-phenylalanine, L-glutamic acid, glycine, L-isoleucine, L-leucine, L-lysine, L-methionine, Lphenylalanine, L-threonine and L-tryptophan at final concentrations of $10 \mathrm{mM}$. Basal medium containing $\mathrm{NH}_{4} \mathrm{NO}_{3}$ $(0.01 \% \mathrm{w} / \mathrm{v})$ and lacking a nitrogen source were used as positive and negative controls, respectively. All amino acids were prepared as filter-sterilized stock solutions. Colony morphology and acid production were examined on YMA (56) and PY after 2 and $4 \mathrm{~d}$ growth. Growth at $37^{\circ} \mathrm{C}$ and at pH 5.0, 5.5 and 9.0 were evaluated on PY medium. Tolerance to $\mathrm{NaCl}$ at concentrations of $1.0,1.5,2.0$ and $2.5 \%(\mathrm{w} / \mathrm{v})$ was determined on YMA. Ability to grow in LB medium was determined with $5 \mathrm{ml}$ broth. Growth rate was determined in YM broth by following the increase in culture optical density spectrophotometrically at $600 \mathrm{~nm}$ which was used to derive the generation times (56) of each of the cultures tested.

Plant trapping tests. Surface sterilized, germinated seeds of Sesbania herbacea and Galega orientalis were used for trapping rhizobia from Mexican soils (from Cuernavaca, Morelos) in pots under natural sunlight, to test if $R$. galegae or other rhizobia could be recovered. Nodules were collected from 2-month-old plants. Isolates were identified by PCRRFLP of 16S rRNA genes and electrophoretic plasmid profiles using the methods mentioned above. 


\section{RESULTS}

\section{Isolation of the bacterial symbionts of Sesbania herbacea}

Only root nodules of Sesbania herbacea were collected from the flooded fields of Sierra de Huautla since stem nodules were not observed. The appearance of the nodules was as if they were covered with a cotton-like material. One hundred and four rhizobial isolates were obtained, which we considered fast-growing because single colonies of $2 \mathrm{~mm}$ diameter were formed on PY medium after $2 \mathrm{~d}$ incubation at $28^{\circ} \mathrm{C}$. These colonies were round, white and shiny and became gummy after incubating them for an additional $3 \mathrm{~d}$. More exopolysaccharides were produced on YMA than on PY medium.

\section{PCR-RFLP analysis of the 16S rRNA genes}

The fingerprint patterns of the 16S rRNA gene PCR products of all of the 104 isolates digested with the four restriction enzymes were compared with those obtained with type or reference strains for the defined species (Table 1). The fingerprint patterns among the 104 isolates were identical to each other and with the patterns observed with the type strain for $R$. galegae,
HAMBI $540^{\mathrm{T}}$. The patterns obtained with the remaining type strains for the various species were distinguishable from those of $R$. galegae and the isolates, and clustered according to their phylogenetic relationships (data not shown) as previously reported $(26,35)$.

\section{MLEE}

Only 66 randomly chosen isolates were included in this analysis because no differences among the 104 isolates by fingerprint analysis of the $16 \mathrm{~S}$ rRNA genes were detected. However, we included 23 strains of $R$. galegae in addition to the reference strain because the PCRRFLP pattern of the 16S rRNA genes of HAMBI $540^{\mathrm{T}}$ and those of the Sesbania isolates were identical. Three and 10 ETs were identified among the Sesbania isolates and the strains of R. galegae, respectively (Tables 1 and 2 ). The genetic diversity among the strains of $R$. galegae was higher than among the isolates from Sesbania herbacea (Table 3). The analysis also included the type strains for Sinorhizobium terangae and Sinorhizobium saheli because they originated from root nodules of Sesbania in Africa. These two species clustered together and were genetically distant $(0 \cdot 94)$ from clusters formed by our Sesbania isolates and the

Table 2. Allele profiles of 12 enzyme loci representing 15 ETs among symbionts of Sesbania and Galega species

For each enzyme locus, the numbers denote a different allele for that locus. The absence of enzyme activity is scored as a null character state (-). Abbreviations: PGI, phosphoglucose isomerase; MDH, malate dehydrogenase; IDH, isocitrate dehydrogenase; G6P, glucose-6-phosphate dehydrogenase; PGM, phosphoglucomutase; ME, malic enzyme; HEX, hexokinase; $\mathrm{XDH}$, xanthine dehydrogenase; ADK, adenylate kinase; ALD, alanine dehydrogenase; EST, esterase; IPO, indophenol oxidase.

\begin{tabular}{|c|c|c|c|c|c|c|c|c|c|c|c|c|c|}
\hline \multirow[t]{2}{*}{ ET } & \multirow{2}{*}{$\begin{array}{c}\text { Reference } \\
\text { strain }\end{array}$} & \multicolumn{12}{|c|}{ Alleles at indicated enzyme Ioci } \\
\hline & & PGI & MDH & IDH & G6P & PGM & ME & HEX & XDH & ADK & ALD & EST & IPO \\
\hline \multicolumn{14}{|c|}{ Rhizobium huautlense cluster 3} \\
\hline 1 & $\mathrm{~S} 02^{\mathrm{T}}$ & 4 & 4 & 4 & 4 & 4 & 4 & 6 & 4 & 4 & 4 & 3 & 4 \\
\hline 2 & S03 & 4 & 4 & 4 & 4 & 4 & 4 & 4 & 4 & 4 & 4 & 4 & 4 \\
\hline 3 & S103 & 4 & 4 & 4 & 4 & 4 & 4 & 6 & 4 & 4 & 4 & 4 & 4 \\
\hline \multicolumn{14}{|c|}{ Rhizobium galegae cluster 1} \\
\hline 4 & HAMBI 1461 & 4 & 4 & 3 & 4 & 3 & 3 & 6 & 4 & 4 & 6 & 7 & 2 \\
\hline 5 & HAMBI $540^{\mathrm{T}}$ & 6 & 4 & 3 & 6 & 3 & 3 & 6 & 4 & 4 & 6 & 8 & 2 \\
\hline 6 & HAMBI 1207 & 7 & 4 & 3 & 6 & 2 & 3 & 7 & 4 & 4 & 6 & 8 & 2 \\
\hline 7 & HAMBI 1428 & 4 & 4 & 3 & 6 & 3 & 3 & 6 & 4 & 4 & 6 & 8 & 2 \\
\hline \multicolumn{14}{|c|}{ Rhizobium galegae cluster 2} \\
\hline 8 & HAMBI 1143 & 4 & 4 & 4 & 6 & 4 & 4 & 7 & 4 & 4 & 6 & 3 & 2 \\
\hline 9 & $59 \mathrm{~A} 2$ & 4 & 4 & 4 & 4 & 4 & 4 & 8 & 4 & 4 & 6 & 2 & 1 \\
\hline 10 & HAMBI 1146 & 4 & 4 & 4 & 4 & 4 & 4 & 8 & 4 & 4 & 6 & 3 & 2 \\
\hline 11 & HAMBI 1145 & 7 & 4 & 4 & 4 & 4 & 4 & 5 & 4 & 6 & 6 & 7 & 2 \\
\hline 12 & HAMBI 1185 & 6 & 4 & 4 & 6 & 4 & 4 & 4 & 4 & 4 & 6 & 7 & 2 \\
\hline 13 & HAMBI 1186 & 7 & 4 & 4 & 4 & 4 & 4 & 6 & 4 & 4 & 6 & 7 & 2 \\
\hline \multicolumn{14}{|c|}{ Sinorhizobium terangae } \\
\hline 14 & ORS 1009 & 8 & 8 & 8 & 9 & 6 & 7 & 6 & - & 9 & 9 & 9 & 9 \\
\hline \multicolumn{14}{|c|}{ Sinorhizobium saheli } \\
\hline 15 & ORS 609 & 8 & 8 & 8 & 6 & 6 & 8 & 6 & - & 9 & 9 & 9 & 9 \\
\hline
\end{tabular}


Table 3. Genetic diversity $(h)$ at 12 enzyme loci among $R$. huautlense and $R$. galegae

See Table 2 for abbreviations and the cluster composition.

\begin{tabular}{|c|c|c|c|c|c|c|c|c|}
\hline \multirow[t]{2}{*}{ Enzyme } & \multicolumn{2}{|c|}{$\begin{array}{l}\text { Cluster } 1 \\
\text { (4 ETs) }\end{array}$} & \multicolumn{2}{|c|}{$\begin{array}{c}\text { Cluster } 2 \\
\text { (6 ETs) }\end{array}$} & \multicolumn{2}{|c|}{$\begin{array}{c}\text { Clusters } 1+2 \\
\text { (10 ETs) }\end{array}$} & \multicolumn{2}{|c|}{$\begin{array}{c}\text { Cluster } 3 \\
\text { (3 ETs) }\end{array}$} \\
\hline & Alleles & $h$ & Alleles & $\boldsymbol{h}$ & Alleles & $\boldsymbol{h}$ & Alleles & $h$ \\
\hline PGI & 2 & 0.833 & 3 & 0.689 & 3 & 0.733 & 1 & 0 \\
\hline $\mathrm{MDH}$ & 1 & 0 & 1 & 0 & 1 & 0 & 1 & 0 \\
\hline IDH & 1 & 0 & 1 & 0 & 2 & 0.533 & 1 & 0 \\
\hline G6P & 2 & 0.500 & 2 & 0.534 & 2 & 0.556 & 1 & 0 \\
\hline PGM & 2 & $0 \cdot 500$ & 1 & 0 & 3 & 0.600 & 1 & 0 \\
\hline $\mathrm{ME}$ & 1 & 0 & 1 & 0 & 2 & 0.533 & 1 & 0 \\
\hline HEX & 2 & 0.500 & 5 & 0.932 & 5 & $0 \cdot 822$ & 2 & 0.668 \\
\hline $\mathrm{XDH}$ & 1 & 0 & 1 & 0 & 1 & 0 & 1 & 0 \\
\hline ADK & 1 & 0 & 2 & $0 \cdot 334$ & 2 & $0 \cdot 200$ & 1 & 0 \\
\hline ALD & 1 & 0 & 1 & 0 & 1 & 0 & 1 & 0 \\
\hline EST & 2 & 0.500 & 3 & 0.733 & 4 & 0.778 & 2 & 0.668 \\
\hline IPO & 1 & 0 & 2 & $0 \cdot 334$ & 2 & $0 \cdot 200$ & 1 & 0 \\
\hline Mean & $1 \cdot 4$ & $0 \cdot 236$ & 1.9 & $0 \cdot 300$ & $2 \cdot 3$ & 0.409 & $1 \cdot 2$ & $0 \cdot 111$ \\
\hline
\end{tabular}

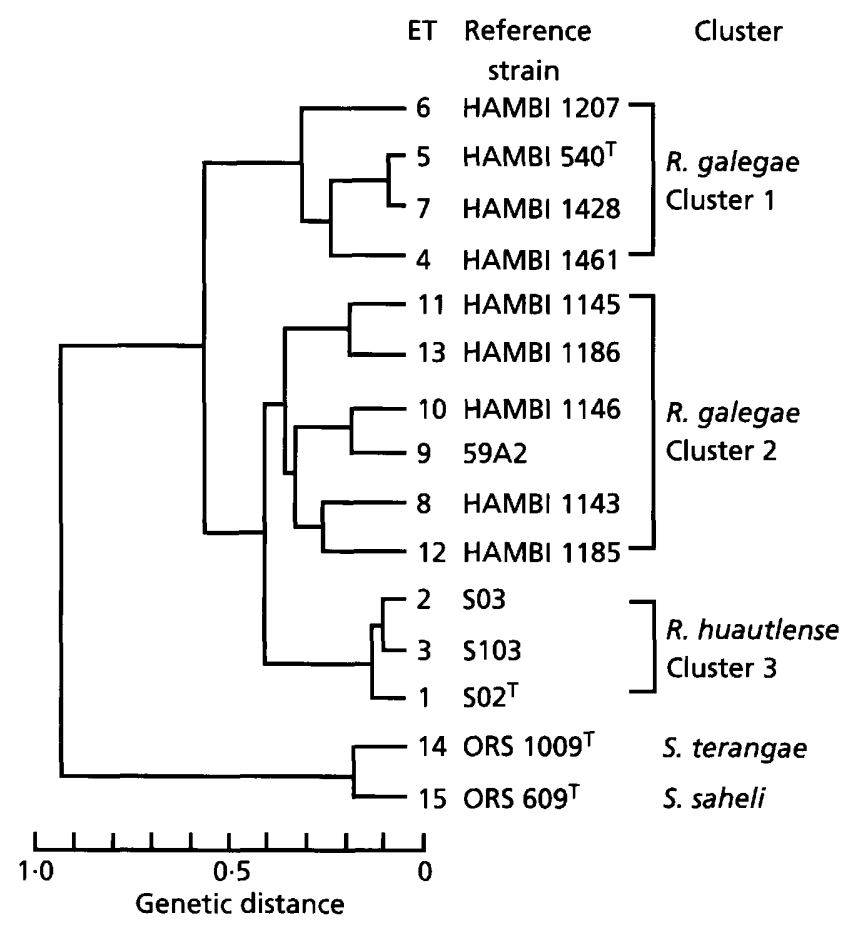

Fig. 1. Genetic relationships among Rhizobium huautlense, $R$. galegae and type strains for Sinorhizobium saheli and Sinorhizobium terangae based on the MLEE data. In the case of $R$. huautlense the three strains indicated represent three ETs among the 66 isolates that were analysed. In the case of $R$. galegae, strains indicated represent 10 ETs among 23 strains that were analysed.

strains from the Galega host plant species (Fig. 1). Ten ETs were identified among the strains of $R$. galegae which formed two clusters (clusters 1 and 2) separated at a genetic distance of 0.56 . The two clusters identified among $R$. galegae corresponded with hosts nodulated since the strains of cluster 1 originated from $G$. orientalis, except HAMBI 1207, and those of cluster 2 from $G$. officinalis (28). Three ETs forming a single cluster (cluster 3 ) were identified among the 66 isolates from Sesbania herbacea. Cluster 3 and cluster 2 were separated at a genetic distance of 0.39 .

The $I_{\mathrm{A}}$ values were $1.49 \pm 0.38$ when all the three clusters, 1, 2 and 3 , were considered together, and $1.64 \pm 0.43$ and $1.00 \pm 0.46$, respectively, when the two subsets, clusters 1 and 2 or clusters 2 and 3 were analysed. The fact that all of these $I_{\mathrm{A}}$ values differed significantly from zero might indicate linkage disequilibrium relationships between these three clusters. However, results of linkage disequilibrium analysis might be questionable when sample sizes are small as is the case in each of the three clusters 1,2 and 3.

\section{DNA G + C content and DNA-DNA hybridization}

The DNA $\mathrm{G}+\mathrm{C}$ contents for the two representative isolates, $\mathrm{S} 02^{\mathrm{T}}$ and $\mathrm{S} 03$, were 57.0 and $58.9 \mathrm{~mol} \%$, respectively. Four isolates from Sesbania herbacea, which represented the three ETs, shared DNA homology above $70 \%$ as determined by the filter method (Table 3). The DNA homology of isolate $\mathrm{S} 02^{\mathrm{T}}$ and the type strains of the described species, including $R$. galegae, ranged from 9 to $22 \%$ determined with the filter method. When determined by the hydroxyapatite method the DNA homology of isolate $\mathrm{S} 02^{\mathrm{T}}$ with the $R$. galegae type strain HAMBI $540^{\mathrm{T}}$ and strain $59 \mathrm{~A} 2$ was 12 and $26 \%$, respectively. The DNA homology between strain 59A2 and HAMBI $540^{\mathrm{T}}$ of $R$. galegae representing cluster 2 and cluster 1 in the MLEE analysis was 40 and $65 \%$ as determined by the filter 


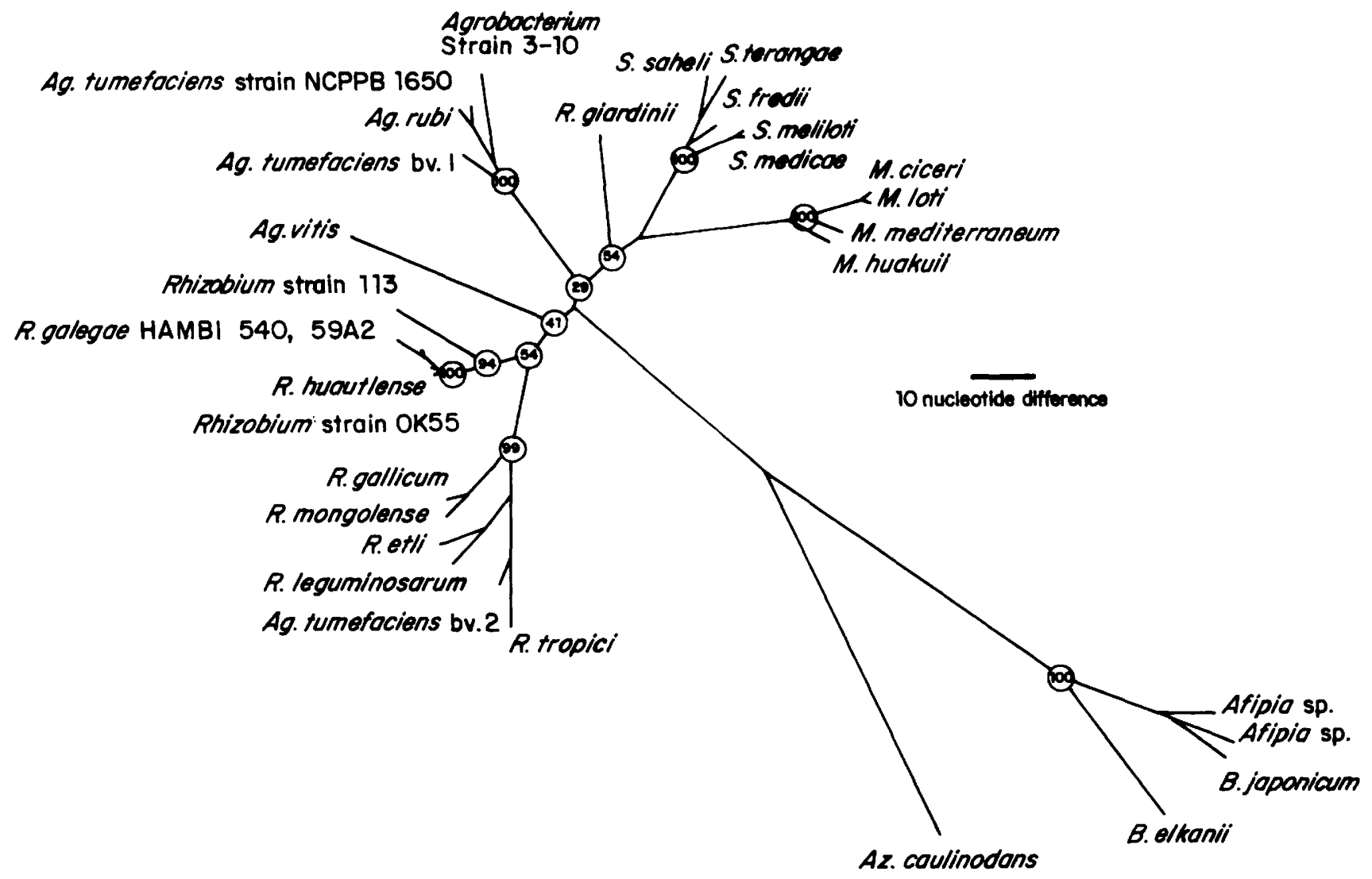

Fig. 2. Phylogenetic relationships of Rhizobium huautlense and $R$. galegae within the $\alpha$-Proteobacteria based upon aligned sequences of the small subunit rRNA genes. Jukes-Cantor distances were derived from the aligned sequences to construct an optimal unrooted tree using the neighbour-joining method. The levels of support for the presence of several relevant nodes are indicated. Representative sequences in the tree obtained from GenBank which were used in the phylogenetic analysis were: Agrobacterium rubi (D14503), Agrobacterium vitis (D14502), Agrobacterium tumefaciens bv. 2 strain NCPPB 2991 (D14501), Agrobacterium tumefaciens strain NCPPB 1650 (D14506), Agrobacterium tumefaciens bv. 1 strain NCPPB 2437 (D14500), Agrobacterium sp. strain 3-10 (Z30542), Afipia clevelandensis (M69186), Afipia felis (M65248), Azorhizobium caulinodans (X94200), Bradyrhizobium elkanii (U35000), B. japonicum (U69638), Mesorhizobium ciceri (U07934), M. huakuii (D13431), M. loti (X67229), M. mediterraneum (L38825), Rhizobium etli (U28916), R. galegae (X67226), R. gallicum (U86343), R. giardinii (U86344), R. leguminosarum bv. viciae (U29386), R. mongolense (U89817), $R$. tropici (U89832), Rhizobium sp. strain OK55 (D14510), Rhizobium sp. strain 113 (D14512), Sinorhizobium fredii (X67231), Sinorhizobium medicae (L39882), Sinorhizobium meliloti (X67222), Sinorhizobium saheli (X68390) and Sinorhizobium terangae (X68387). The sequences were aligned using the PILEUP program and the aligned sequences were analysed using the DNADIST and NEIGHBOR programs of the software package PHYLIP version $3.5 \mathrm{C}(17)$ and the tree was constructed using RETREE and DRAWTREE. The bootstrap analysis was done using the Molecular Evolutionary Genetics Analysis (MEGA) package version $1.01(24)$.

and hydroxyapatite methods, respectively. The DNA homology values of 59A2 and several additional strains of $R$. galegae varied between 32 and $94 \%$ when determined by the filter method, which in some cases was lower than previously reported $(29,57)$.

\section{Phylogeny of the isolates based upon 165 rRNA gene sequences}

Phylogeny was reconstructed with only the representative isolate $\mathrm{S} 02^{\mathrm{T}}$ since fingerprint patterns obtained by PCR-RFLP analysis of the $16 \mathrm{~S}$ rRNA gene products of all 104 isolates were identical. However, the $16 \mathrm{~S}$ rRNA gene sequence of 59A2 also was determined to reconstruct the phylogeny of the cluster 2 strains of $R$. galegae. The 16S rRNA gene sequence of isolate $\mathrm{S} 02^{\mathrm{T}}$ was most similar to that of Sesbania strain OK $55(99.9 \%$ ) and was 99.5 and $99.7 \%$ similar to those of $R$. galegae HAMBI $540^{T}$ and 59A2. The nucleotide sequence of the 16S rRNA gene of isolate $\mathrm{S} 02^{\mathrm{T}}$ was less similar to that of Agrobacterium vitis $(96 \cdot 1 \%)$ than to that of $R$. leguminosarum $(96 \cdot 3 \%)$. Apart from R. galegae, within the genus Rhizobium the 16S rRNA gene sequence of isolate $\mathrm{S} 02^{\mathrm{T}}$ and that of $R$. mongolense (55) was most similar $(96.8 \%)$. The nucleotide sequence similarities of the 16S rRNA genes of 59A2 with those of $R$. leguminosarum, $R$. mongolense and Agrobacterium vitis were $96.2,96.7$ and $96.2 \%$, 
respectively. The aligned $16 \mathrm{~S}$ rRNA gene sequences were used to reconstruct a phylogenetic tree (Fig. 2). The representative isolate from Sesbania herbacea, $\mathrm{S} 02^{\mathrm{T}}$, clustered with strains HAMBI $540^{\mathrm{T}}$ and $59 \mathrm{~A} 2$ of $R$. galegae, and the isolates OK55 and 113 from Sesbania aculeata and Mimosa invisa (41), respectively. The node of this cluster was shared with that of the other species of Rhizobium and Agrobacterium tumefaciens bv. 2 strain NCPPB 2991. In our phylogenetic reconstruction the position of Agrobacterium vitis became uncertain in comparision to previous reports $(46,60)$ since Agrobacterium vitis and $R$. galegae no longer shared a common node. Instead, the branch with Agrobacterium vitis was independent and had a node close to that of the other species of Agrobacterium. However, results of the bootstrap analysis using 500 replications would indicate a low level of confidence in the relative positions of the nodes separating $R$. galegae and $R$. leguminosarum, Rhizobium and Agrobacterium vitis, and Agrobacterium vitis and Agrobacterium tumefaciens bv. 1. We observed shifts in the relative positions of $R$. galegae and Agrobacterium vitis and a change in the confidence values of the positions of these nodes as we reconstructed phylogenies after progressively removing sequences from the alignment. After removing the $16 \mathrm{~S}$ rRNA gene sequences of $\mathrm{S} 02^{\mathrm{T}}, 113$, OK $55,59 \mathrm{~A} 2$, AF3-10, $R$. etli, $R$. gallicum (2) and $R$. mongolense from the alignment, tree topology was restored to that reported by Willems \& Collins (60).

\section{Determinations of plasmid profiles and identification of the symbiotic plasmid}

The majority of the 66 isolates originating from Sesbania herbacea had two plasmids with approximate molecular sizes of 900 and $400 \mathrm{~kb}$ (Table 1, Fig. 3). We concluded that the symbiotic plasmid was the smaller of the two since it hybridized with probes containing the cloned nod and nif genes. However, only the $900 \mathrm{~kb}$ plasmid was observed with isolate S41 and in the case of isolate $S 172$ an additional plasmid of $220 \mathrm{~kb}$ was identified. No plasmid bands were observed in isolates $\mathrm{S} 32$ and S182, however by hybridization to nif genes we observed bands that could respond to very large megaplasmids (data not shown). Strains of $R$. galegae had plasmids which differed in molecular size from those detected in the isolates from Sesbania herbacea (Table 1). All the strains of $R$. galegae had a megaplasmid $(>1000 \mathrm{~kb})$ and either one or no additional plasmids. The molecular size of the second plasmid was either 340 or $180 \mathrm{~kb}$. Cluster 1 strains had only the megaplasmid (ETs 4 and 5), or the megaplasmid and a $180 \mathrm{~kb}$ plasmid (ETs 6 and 7). The cluster 2 strains either had the megaplasmid alone (ETs 9 and 12), or the megaplasmid and either the $340 \mathrm{~kb}$ plasmid (ETs 8 and 11 ) or the $180 \mathrm{~kb}$ plasmid (ETs 10 and 13). The megaplasmid of HAMBI $540^{\mathrm{T}}$ was identified as the symbiotic plasmid, which agreed with previous reports $(23,40)$.

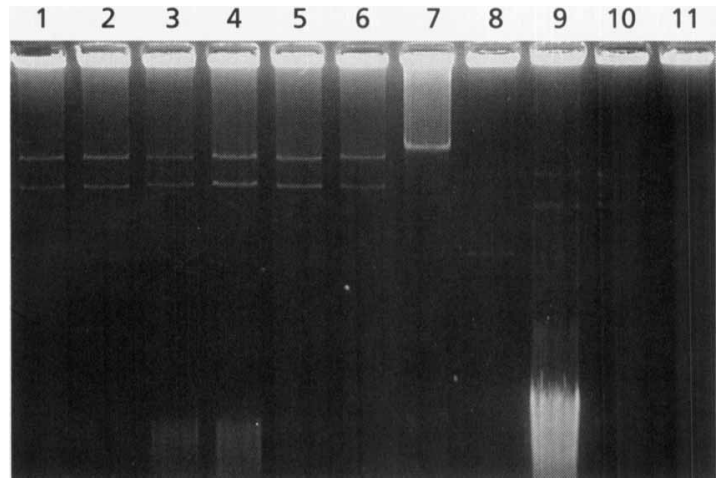

Fig. 3. Plasmids of Rhizobium huautlense. Plasmids were visualized by using the modified Eckhardt procedure (20) and their mobilities were determined in $0.7 \%$ agarose gels. Lanes: $1-6, R$. huautlense $\mathrm{S} 02^{\top}$, S94, S03, S11, S103, S124, representing three ETs, respectively; $7, R$. galegae $\mathrm{HAMBI} 540^{\top} ; 8$, Azorhizobium caulinodans ORS 571; 9, Agrobacterium tumefaciens IAM 13129; 10, R. etli CFN $42^{\top}$ cured of the $630 \mathrm{~kb}$ plasmid; $11, R$. tropici CFN 299. The approximate molecular size of the plasmids is shown in Table 1.

\section{Phenotypic characterization}

The distinctive phenotypic characters of 15 isolates from Sesbainia herbacea, nine strains of $R$. galegae and the type strain of Agrobacterium vitis are listed in Table 4. The isolates could be distinguished from $R$. galegae by growth on YMA at $40^{\circ} \mathrm{C}$ or at $\mathrm{pH} 9 \cdot 0$. Growth of the isolates on the basal medium was significantly improved by the addition of thiamin but not pyridoxine. Strains of $R$. galegae did not grow on basal medium supplemented with the two vitamins because of the requirement of calcium panthotenate as growth factor. Differences between these two groups also were resistance to ampicillin and the utilization of adenine, methionine and dulcitol. Growth in LB or on YMA in the presence of $1.5 \% \mathrm{NaCl}$ distinguished Agrobacterium vitis from the 15 isolates from Sesbania herbacea and the nine strains of $R$. galegae. Further distinctive characters of the Agrobacterium vitis type strain were resistance to chloramphenicol, growth with glycine and cystine, the production of acid with adenine and maltose, and the production of alkaline with aspartate and glutamate. Strains of $R$. galegae belonging to the two clusters could not be distinguished by phenotypic characters.

The isolates from Sesbania herbacea did not grow on YMA at $\mathrm{pH} 4 \cdot 5$. All produced acid on YMA and were resistant to $300 \mu \mathrm{g}$ lincomycin $\mathrm{ml}^{-1}$ and $5 \mu \mathrm{g} \mathrm{ml}^{-1}$ each of erythromycin, neomycin and kanamycin. All were sensitive to $5 \mu \mathrm{g}$ tetracycline $\mathrm{ml}^{-1}, 50 \mu \mathrm{g} \mathrm{ml}^{-1}$ each of ampicillin, chloromycin, gentamicin and neomycin, and $100 \mu \mathrm{g}$ kanamycin $\mathrm{ml}^{-1}$. All could grow and produce acid with L-leucine, L-lysine, L-tryptophan, $\mathrm{L}$-arginine, L-isoleucine and L-phenylalanine as sole nitrogen sources, and did not grow with $p$-flouro-DLphenylalanine and anthranilic acid. All used D-xylose, D-fructose, inositol, D-galactose, D-glucose, melobiose, 
Table 4. DNA-DNA hybridization of $R$. huautlense strain $\mathrm{S}^{2} 2^{\top}$ and $R$. galegae strain 59A2 with type strains of related species

DNA-DNA hybridization was overnight at $65^{\circ} \mathrm{C}$ and the membranes were washed twice in $2 \times$ $\mathrm{SSC}$ at room temperature for $10 \mathrm{~min}$ and in $1 \times \mathrm{SSC}$ for $15 \mathrm{~min}$ at $65^{\circ} \mathrm{C}$. Values are means \pm standard error.

\begin{tabular}{|c|c|c|c|}
\hline \multirow[t]{2}{*}{ Species } & \multirow[t]{2}{*}{ Strain } & \multicolumn{2}{|c|}{ DNA homology (\%) with: } \\
\hline & & $\mathbf{S} 02^{\mathrm{T}}$ & 59A2 \\
\hline \multirow[t]{4}{*}{ Rhizobium huautlense } & $\mathrm{S} 02^{\mathrm{T}}$ & 100 & $16 \pm 3$ \\
\hline & S94 & $102 \pm 8$ & \\
\hline & $\mathrm{S} 03$ & $80 \pm 10$ & $18 \pm 1$ \\
\hline & S103 & $79 \pm 3$ & \\
\hline \multicolumn{4}{|l|}{ Rhizobium galegae } \\
\hline \multirow[t]{2}{*}{ Cluster 1} & HAMBI $540^{\mathrm{T}}$ & $22 \pm 2$ & $41 \pm 3$ \\
\hline & HAMBI 1141 & $17 \pm 3$ & $32 \pm 3$ \\
\hline \multirow[t]{6}{*}{ Cluster 2} & HAMBI 1146 & & $94 \pm 6$ \\
\hline & HAMBI 1183 & $21 \pm 3$ & $44 \pm 5$ \\
\hline & HAMBI 1143 & & $40 \pm 2$ \\
\hline & HAMBI 1185 & & $36^{-}$ \\
\hline & HAMBI 1191 & & $36 \pm 0$ \\
\hline & $59 \mathrm{~A} 2$ & $24 \pm 1$ & 100 \\
\hline Rhizobium leguminosarum & USDA $2370^{\mathrm{T}}$ & $20 \pm 2$ & \\
\hline Bradyrhizobium japonicum & USDA $6^{\mathrm{T}}$ & $9 \pm 1$ & \\
\hline Azorhizobium caulinodans & ORS $571^{\mathrm{T}}$ & $9 \pm 0$ & \\
\hline Mesorhizobium loti & NZP $2213^{\mathrm{T}}$ & $14 \pm 1$ & \\
\hline Sinorhizobium meliloti & USDA $1002^{\mathrm{T}}$ & $13 \pm 0$ & \\
\hline Sinorhizobium saheli & ORS $609^{\mathrm{T}}$ & $13 \pm 0$ & \\
\hline Sinorhizobium terangae & ORS $1009^{\mathrm{T}}$ & $13 \pm 0$ & \\
\hline Agrobacterium vitis & IAM $14140^{\mathrm{T}}$ & $15 \pm 1$ & \\
\hline Agrobacterium rubi & IAM $13569^{\mathrm{T}}$ & $13 \pm 0$ & \\
\hline Agrobacterium tumefaciens & IAM $13129^{\mathrm{T}}$ & $16 \pm 0$ & \\
\hline Agrobacterium rhizogenes & IAM $13570^{\mathrm{T}}$ & $14 \pm 1$ & \\
\hline
\end{tabular}

D-arabinose, rhamnose, fumarate, succinate and sucrose as sole carbon substrates for growth, but propionate was not utilized.

\section{Nodulation tests}

R. galegae HAMBI $540^{\mathrm{T}}$ did not nodulate Sesbania herbacea and isolate $\mathrm{S} 02^{\mathrm{T}}$ did not nodulate $G$. offcinalis. Besides nodulation of the original trap host, $\mathrm{S} 02^{\mathrm{T}}$ also nodulated $L$. leucocephala, Sesbania rostrata and $T$. repens, but nodules were small and ineffective with the latter two legumes. Although the nodules on L. leucocephala were small, improved plant growth compared to the uninoculated control indicated that a nitrogen-fixing symbiosis had been established.

\section{Plant trapping tests}

Ten plants of Galega orientalis did not form nodules in soils from Cuernavaca. Sesbania herbacea plants formed root nodules and some nodule-like structure on the stems. The majority of the root nodules were formed by isolates which had identical RFLP patterns of $16 \mathrm{~S}$ rRNA genes with Mesorhizobium cluster U strain ORS 1037. The other isolates were similar to $R$. tropici B strain CIAT $899^{\mathrm{T}}$ and $R$. etli CFN $42^{\mathrm{T}}$ according to the $16 \mathrm{~S}$ rRNA gene RFLP analysis. No isolate was similar to those isolated from Sierra de Huautla. One $R$. tropici type-B-like isolate was checked for the plasmid profiles and it showed three bands which were totally different from those of all isolates from flooded fields at Sierra de Huautla. Different bacteria were isolated from each of the nodule-like stem structures. Some of them had RFLP patterns of 16S rRNA genes similar to Sinorhizobium species. Further work is needed to test the nodulation ability and taxonomic positions of these isolates.

\section{DISCUSSION}

The ability of Sesbania species to nodulate is welldocumented $(1,11)$. Several rhizobial symbionts of Sesbania species originating from plants growing in Africa have been classified within the genera Azorhizobium (15) and Sinorhizobium (11). However, there are some indications that species of Sesbania growing 
outside the African continent form symbioses with Rhizobium, but their detailed characterization has not been reported. Isolates originating from Sesbania aculeata growing on the Asian continent (42, 46) would appear to have close phylogenetic affinities with $R$. galegae. The partial description of two Brazilian isolates of Sesbania marginata indicate that soils of the Americas also harbour symbionts of Sesbania within the genus Rhizobium (11). However, their phylogeny was not determined. We chose to work with Sesbania herbacea growing in an undisturbed nature reserve in Mexico, since nodulation of this legume has not been determined. The results of a polyphasic approach to characterize the 104 isolates we obtained led to the conclusion that at least this species of Sesbania growing in the Northern hemisphere of the American continent forms symbioses with bacteria within the genus Rhizobium. It would appear from our data that Sesbania herbacea growing in the nature reserve at Huautla formed symbioses only with Rhizobium, although it is possible that symbionts of other genera were not isolated.

In current reconstructions of the phylogeny of rhizobia based upon 16S rRNA gene sequences, $R$. galegae and the other species within the genus Rhizobium do not appear to share a common ancestry $(46,60,61)$. Instead, $R$. galegae would seem to have more affinity with Agrobacterium vitis, which has prompted a call for the possible revision of $R$. galegae from a species of Rhizobium to one of Agrobacterium (11). In our reconstruction of the phylogeny of $R$. huautlense, the revised phylogenetic tree would tend to indicate common ancestry between $R$. galegae and the type species of the genus, $R$. leguminosarum. This would agree with the reported sequence similarities of the common nodulation genes of $R$. galegae and $R$. leguminosarum (52). The reassignment of $R$. galegae (and Rhizobium huautlense) to a species of Agrobacterium or to a new genus, as was suggested previously $(11,62)$, would not be consistent with the evidence we present.

The diversity among the isolates was very limited. It is possible that these isolates are the most competent rhizobia in flooded conditions for this plant because Sesbania herbacea formed nodules with several other rhizobia, but not $R$. huautlense, when grown in soil. The limited geographic area from which the isolates originated may have contributed to the apparent genetic homogeneity of $R$. huautlense. This is in contrast to the diversity identified within $R$. etli originating from soils in Mexico (50) as well as among the strains of $R$. galegae which were included in our analysis. These isolates and strains originated from a wider geographic region and from either more promiscuous host plants in the case of $R$. etli or from more than one species of host plant in the case of $R$. galegae. This is relevant in the case of $R$. huautlense because it has been suggested that origin and host-plant-specificity may influence bacterial genetic diversity $(7,33$, 49).
Although $R$. huautlense and $R$. galegae are closely related, we suggest that they are distinct species. Our suggestion is supported by their genetic differences mainly based upon the low estimates of DNA relatedness between the two species. Further differences were observed in plasmid content and the size of the symbiotic plasmids. $R$. huautlense and $R$. galegae appear to originate from different geographic regions since there are no native Galega species in Morelos (O. Dorado, unpublished data) and no $R$. galegae in the tested Mexican soils as shown from the plant trapping tests performed. The geographic separation is a barrier to genetic exchange (32) and we propose that this could have led to their divergence into separate species.

We are unable to make conclusions about the possible genetic relationships between $R$. huautlense and Sesbania isolates OK 55 and SIN-1 which originate from Asia because their characterization has not been sufficiently detailed. However, we are able to point out some common features as well as some differences. Both OK 55 (41) and $R$. huautlense require thiamin as a growth factor. The reported DNA G $+\mathrm{C}$ content of OK55 and related strains $(62.7-63.9 \mathrm{~mol} \%)$ is higher than that of $R$. huautlense $(57 \cdot 0-58.9 \mathrm{~mol} \%)$. Characteristics shared by strain SIN-1 (42) and $R$. huautlense are that both harbour two plasmids with the symbiotic genes located on the smaller one, both grow at $37^{\circ} \mathrm{C}$, both utilize gluconate and lactose but not acetate and citrate as sole carbon substrates, both are sensitive to chloramphenicol, erythromycin, kanamycin, tetracycline and streptomycin. Resistance to ampicillin and growth in YMA in the presence of $2 \%$ $\mathrm{NaCl}$ distinguished SIN-1 from $R$. huautlense.

\section{Description of Rhizobium huautlense sp. nov.}

Rhizobium huautlense (huau.tlen'se. N.L. gen. n. huautlense of Huautla, the region in Mexico where the organisms were isolated).

Aerobic, Gram-negative, non-spore-forming rods. Grows on YMA and PY at temperatures up to $40^{\circ} \mathrm{C}$. On YMA, the colonies are circular, cream-coloured, semi-translucent and mucilagenous within 2-4d. Older colonies have a white centre. On PY medium, the colonies produce less polysaccharides than on YMA and acid is produced. The generation time is $2 \cdot 0-2 \cdot 2 \mathrm{~h}$. Growth occurs on YMA supplemented with $1.0 \% \mathrm{NaCl}$ and at $\mathrm{pH} 9 \cdot 0$. Resistant to $300 \mu \mathrm{g}$ lincomycin $\mathrm{ml}^{-1}, 5 \mu \mathrm{g} \mathrm{ml}^{-1}$ each of ampicillin, erythromycin, neomycin and kanamycin. Sensitive to $50 \mu \mathrm{g}$ $\mathrm{ml}^{-1}$ each of ampicillin, chloramphenicol, gentamicin and neomycin, and $5 \mu \mathrm{g}$ tetracycline $\mathrm{ml}^{-1}$, and $100 \mu \mathrm{g}$ kanamycin $\mathrm{ml}^{-1}$. Adenine, L-leucine, L-lysine, methionine, L-tryptophan, L-arginine, L-isoleucine, Lphenylalanine, glutamate and aspartic acid are used as sole nitrogen substrates for growth, but $p$-fluoro-DLphenylalanine and anthranilic acid are not utilized. Dulcitol, inositol, xylose, D-fructose, D-galactose, lactose, melibiose, D-arabinose, rhamnose, fumarate 
and succinate are used as sole carbon substrate for growth, but citrate and propionate are not utilized. Thiamin is required for growth. The species nodulates and forms nitrogen-fixing symbioses with Sesbania herbacea and L. leucocephala. At the molecular level, Rhizobium huautlense is differentiated from related species by cellular plasmid content, the molecular size of the symbiotic plasmid, variation in electrophoretic mobilities of 12 enzyme loci, low estimates of DNA relatedness and by the nucleotide sequence of $16 \mathrm{~S}$ rRNA gene. The DNA $\mathrm{G}+\mathrm{C}$ content is 57.0 $58.9 \mathrm{~mol} \%\left(T_{m}\right) . \mathrm{S} 02^{\mathrm{T}}$ is the type strain of $R$. huautlense, and it has the characteristics given above for the species. All 66 isolates of $R$. huautlense characterized in our study have been deposited in the USDA ARS National Rhizobium Resource Center collection, USA, and in the Culture Collection of Centro de Investigación sobre Fijación de Nitrógeno (CFN) at UNAM, Cuernavaca, Mexico.

\section{ACKNOWLEDGEMENTS}

The plant identification was done by the Herbarium of the Biology Institute, UNAM. We thank Dr M. Hynes for help in plasmid profile analysis, L. E. Fuentes-R. for providing the nif probes. Also, we thank K. Lee Nash for technical assistance. The research was funded by DGAPA grant IN202097 from UNAM, México.

\section{REFERENCES}

1. Allen, O. N. \& Allen, E. K. (1980). The Leguminosae: a source book of characteristics, uses, and nodulation. The University of Wisconsin Press, Madison, WI.

2. Amarger, N., Macheret, V. \& Laguerre, G. (1997). Rhizobium gallicum sp. nov. and Rhizobium giardinii sp. nov. from Phaseolus vulgaris nodules. Int $J$ Syst Bacteriol 47, 996-1006.

3. Becker, M., Ladha, J. K. \& Ottow, J. C. (1988). Stemnodulating legumes as green manure for lowland rice. Philipp J Crop Sci 13, 121-127.

4. Brenner, D. J., Fanning, G. R., Rake, A. V. \& Johnson, K. E. (1969). A batch procedure for thermal elution of DNA from hydroxyapatite. Anal Biochem 28, 447-460.

5. Britten, R. J. \& Kohne, D. E. (1966). Nucleotide sequence repetition in DNA. Carnegie Instit Wash Year Book $\mathbf{6 5}$, 78-106.

6. Brown, A. H. D., Feldman, M. W. \& Nevo, E. (1980). Multilocus structure of natural populations of Hordeum spontaneum. Genetics 96, 523-536.

7. Caballero-Mellado, J. \& Martínez-Romero, E. (1994). Limited genetic diversity in the endophytic sugarcane bacterium Acetobacter diazotrophicus. Appl Environ Microbiol 61, 1532-1537.

8. Chen, W. X., Yan, G. H. \& Li, J. L. (1988). Numerical taxonomic study of fast-growing soybean rhizobia and a proposal that Rhizobium fredii be assigned to Sinorhizobium gen. nov. Int J Syst Bacteriol 38, 392-397.

9. Chirgwin, J. M., Przybyla, A. E., MacDonald, R. J. \& Rutter, W. J. (1979). Isolation of biologically active ribonucleic acid from sources enriched in ribonuclease. Biochemistry 18, 5294-5299.
10. de Faria, S. M., Lewis, G. P., Sprent, J. I. \& Sutherland, J. M. (1989). Occurrence of nodulation in the Leguminosae. New Phytol 111, 617-629.

11. De Lajudie, P., Willems, A., Pot, B. \& 7 other authors (1994). Polyphasic taxonomy of rhizobia: emendation of the genus Sinorhizobium and description of Sinorhizobium meliloti comb. nov., Sinorhizobium saheli sp. nov., and Sinorhizobium teranga sp. nov. Int J Syst Bacteriol 44, 715-733.

12. De Ley, J. (1970). Reexamination of the association between melting point, buoyant density, and chemical base composition of DNA. J Bacteriol 101, 738-754.

13. Dreyfus, B. L. \& Dommergues, Y. R. (1981). Nitrogen-fixing nodules induced by Rhizobium on the stem of the tropical legume Sesbania rostrata. FEMS Microbiol Lett 10, 313-317.

14. Dreyfus, B. L., Elmerich, C. \& Dommergues, Y. R. (1983). Freeliving Rhizobium strain able to grow on $\mathrm{N}_{2}$ as the sole nitrogen source. Appl Environ Microbiol 45, 711-713.

15. Dreyfus, B., Garcia, J. L. \& Gillis, M. (1988). Characterization of Azorhizobium caulinodans gen. nov., sp. nov., a stemnodulating nitrogen-fixing bacterium isolated from Sesbania rostrata. Int J Syst Bacteriol 38, 89-98.

16. Elkan, G. H. (1992). Taxonomy of the rhizobia. Can J Microbiol 38, 446-450.

17. Felsenstein, J. (1993). PHYLIP (phylogenetic inference package) version $3.5 \mathrm{c}$. Department of Genetics, University of Washington, Seattle.

18. Frank, B. (1889). Ueber die Pilzsymbiose der Leguminosen. Ber Dtsch Bot Ges 7, 332-346

19. Geniaux, E., Flores, M., Palacios, R. \& Martínez, E. (1995). Presence of megaplasmids in Rhizobium tropici and further evidence of differences between the two $R$. tropici subtypes. Int J Syst Bacteriol 45, 392-394.

20. Hynes, M. F. \& McGregor, N. F. (1990). Two plasmids other than the nodulation plasmid are necessary for formation of nitrogen-fixing nodules by Rhizobium leguminosarum. Mol Microbiol 4, 567-574.

21. Jarvis, B. D. W., van Berkum, P., Chen, W. X., Nour, S. M., Fernandez, M. P., Cleyet-Marel, J. C. \& Gillis, M. (1997). Transfer of Rhizobium loti, Rhizobium huakuil, Rhizobium ciceri, Rhizobium mediterraneum, and Rhizobium tianshanense to a new genus: Mesorhizobium. Int J Syst Bacteriol 47, 895-898.

22. Jordan, D. C. (1984). Family III. Rhizobiaceae. In Bergey's Manual of Systematic Bacteriology, vol. 1, pp. 234-242. Edited by N. R. Krieg \& J. G. Holt. Baltimore: Williams \& Wilkins.

23. Kaijalainen, S. \& Lindström, K. (1989). Restriction fragment length polymorphism analysis of Rhizobium galegae strains. $J$ Bacteriol 171, 5562-5566.

24. Kumar, S., Tamura, K. \& Nei, M. (1993). MEGA: Molecular Evolutionary Genetics Analysis, version 1.01. The Pennsylvania State University, University Park, PA 16802.

25. Ladha, J. K., Pareek, R. P. \& Becker, M. (1992). Stemnodulating legume- Rhizobium symbiosis and its agronomic use in lowland rice. Adv Soil Sci 20, 147-192.

26. Laguerre, G., Allard, M., Revoy, F. \& Amarger, N. (1994). Rapid identification of rhizobia by restriction fragment length polymorphism analysis of PCR-amplified 16S rRNA genes. Appl Environ Microbiol 61, 56-63.

27. Leonard, L. T. (1943). A simple assembly for use in the testing for cultures of rhizobia. $J$ Bacteriol 45, 523-527. 
28. Lindström, K. (1989). Rhizobium galegae, a new species of legume root nodule bacteria. Int J Syst Bacteriol 39, 365-367.

29. Lindström, K. \& Jarvis, B. D. W. (1983). DNA homology, phage-typing, and cross-nodulation studies of rhizobia infecting Galega species. Can J Microbiol 29, 781-789.

30. Martínez, E., Palacios, R. \& Sanchez, F. (1987). Nitrogenfixing nodules induced by Agrobacterium tumefaciens harboring Rhizobium phaseoli plasmids. J Bacteriol 169, 2828-2834.

31. Martínez-Romero, E., Segovia, L., Mercante, F. M., Franco, A. A., Graham, P. \& Pardo, M. A. (1991). Rhizobium tropici, a novel species nodulating Phaseolus vulgaris L. beans and Leucaena sp. trees. Int $J$ Syst Bacteriol 41, 417-426.

32. Maynard Smith, J., Smith, N. H., O'Rourke, M. \& Spratt, B. J. (1993). How clonal are bacteria? Proc Natl Acad Sci USA 90, 4384-4388.

33. McArthur, J. V., Kovacic, D. A. \& Smith, M. H. (1988). Genetic diversity in natural populations of a soil bacterium across a landscape gradient. Proc Natl Acad Sci USA 85, 9621-9624.

34. Morett, E., Moreno, S. \& Espin, G. (1988). Transcription analysis of the three nif $\mathrm{H}$ genes of Rhizobium phaseoli with gene fusion. Mol Gen Genet 213, 499-504.

35. Moyer, C. L., Tiedje, J. M., Dobbs, F. C. \& Karl, D. M. (1996). A computer-simulated restriction fragment length polymorphism analysis of bacterial small-subunit rRNA genes: efficacy of selected tetrameric restriction enzymes for studies of microbial diversity in nature. Appl Environ Microbiol 62, 2501-2507.

36. Navarro, R. B., Vargas, A. A. T., Schröder, E. C. \& van Berkum, P. (1993). Uptake hydrogenase (Hup) in common bean (Phaseolus vulgaris) symbioses. Appl Environ Microbiol 60, 4162-4165.

37. Nei, M. \& Li, W. H. (1979). Mathematical model for studying genetic variation in terms of restriction endonucleases. Proc Natl Acad Sci USA 76, 5269-5273.

38. Noel, K. D., Sánchez, F., Fernandez, L., Leemans, J. \& Cevallos, M. A. (1984). Rhizobium phaseoli symbiotic mutants with transposon Tn5 insertions. J Bacteriol 158, 148-155.

39. Novikova, N. I., Pavlova, E. A., Vorobjev, N. I. (1994). Numerical taxonomy of Rhizobium strains from legumes of the temperate zone. Int $J$ Syst Bacteriol 44, 734-742.

40. Novikova, N. I. \& Safronova, V. (1992). Transconjugants of Agrobacterium radiobacter harbouring sym genes of $R$. galegae can form an effective symbiosis with Medicago sativa. FEMS Microbiol Lett 93, 262-268.

41. Oyaizu, H., Matsumoto, S., Minamisawa, K. \& Gamou, T. (1993). Distribution of rhizobia in leguminous plants surveyed by phylogenetic identification. $J$ Gen Appl Microbiol 39, 339-354.

42. Rana, D. \& Krishnan, H. B. (1995). A new root-nodulating symbiont of the tropical legume Sesbania, Rhizobium sp. SIN-1, is closely related to $R$. galegae, a species that nodulates temperate legumes. FEMS Microbiol Lett 134, 19-25.

43. Rhoads, D. D. \& Roufa, D. J. (1989). Seqaid II (tm) version 3.5. Molecular Genetics Laboratory, Kansas State University.

44. Rinaudo, G., Orenga, S., Fernandez, M. P., Meugnier, H. \& Bardin, R. (1991). DNA homologies among members of the genus Azorhizobium and other stem-nodulating bacteria isolated from the tropical legume Sesbania rostrata. Int $J$ Syst Bacteriol 41, 114-120.

45. Romero, D., Brom, S., Martínez-S., J., de Lourdes Girard, M., Palacios, R. \& Davila, G. (1991). Amplification and deletion of a nod-nif region in the symbiotic plasmid of Rhizobium phaseoli. J Bacteriol 173, 2435-2441.

46. Sawada, H., leki, H., Oyaizu, H. \& Matsumoto, S. (1993). Proposal for rejection of Agrobacterium tumefaciens and revised descriptions for the genus Agrobacterium and for Agrobacterium radiobacter and Agrobacterium rhizogenes. Int J Syst Bacteriol 43, 694-702.

47. Segovia, L., Young, J. P. W. \& Martínez-Romero, E. (1993). Reclassification of American Rhizobium leguminosarum biovar phaseoli type I strains as Rhizobium etli sp. nov. Int J Syst Bacteriol 43, 374-377.

48. Selander, R. K., Caugant, D. A., Ochman, H., Musser, J. M., Gilmour, M. N. \& Whittam, T. S. (1986). Methods of multilocus enzyme electrophoresis for bacterial population genetics and systematics. Appl Environ Microbiol 51, 873-884.

49. Selander, R. K., McKinney, R. M., Whittam, T. S., Bibb, W. F., Brenner, D. J., Nolte, F. S. \& Pattison, P. E. (1985). Genetic structure of populations of Legionella pneumophila. $J$ Bacteriol 163, 1021-1037.

50. Souza, V., Eguiarte, L., Avila, G., Cappello, R., Gallardo, C., Montoya, J. \& Piñero, D. (1994). Genetic structure of Rhizobium etli biovar phaseoli associated with wild and cultivated bean plants (Phaseolus vulgaris and Phaseolus coccineus) in Morelos, Mexico. Appl Environ Microbiol 61, 1261-1268.

51. Souza, V., Nguyen, T. T., Hudson, R. R., Piñero, D. \& Lenski, R. E. (1992). Hierarchical analysis of linkage disequilibrium in Rhizobium populations : evidence for sex? Proc Natl Acad Sci USA 89, 8389-8393.

52. Suomnen, L., Jugens, G., Roos, C., Paulin, L. \& Lindström, K. (1995). Identification of nodulation gene clusters in $R h i$ zobium galegae strain HAMBI 1174. In Nitrogen Fixation: Fundamentals and Applications, p. 333. Edited by I. A. Tikhonovich, N. A. Provorov, V. I. Romanov \& W. E. Newton. Dordrecht, The Netherlands: Kluwer.

53. van Berkum, P. (1990). Evidence for a third uptake hydrogenase phenotype among the soybean bradyrhizobia. Appl Environ Microbiol 56, 3835-3841.

54. van Berkum, P., Beyene, D. \& Eardly, B. D. (1996). Phylogenetic relationships among Rhizobium species nodulating the common bean (Phaseolus vulgaris L.). Int J Bacteriol 46, 240-244.

55. van Berkum, P., Beyene, D., Bao, G., Campbell, T. A. \& Eardly, B. D. (1998). Rhizobium mongolense sp. nov. is one of three rhizobial genotypes identified which nodulate and form nitrogen-fixing symbioses with Medicago ruthenica [(L.) Ledebour]. Int J Syst Bacteriol 48, 13-22.

56. Vincent, J. M. (1970). A manual for the practical study of root-nodule bacteria. IBP handbook 15. Oxford: Blackwell Scientific Publications.

57. Wedlock, D. N. \& Jarvis, B. D. W. (1986). DNA homologies between Rhizobium fredii, rhizobia that nodulate Galega sp., and other Rhizobium and Bradyrhizobium species. Int $J$ Syst Bacteriol 36, 550-558.

58. Weisburg, W. G., Barns, S. M., Pelletier, D. A. \& Lane, D. J. (1991). 16S ribosomal DNA amplification for phylogenetic study. J Bacteriol 173, 697-703. 
59. Whittam, T. S., Ochman, H. \& Selander, R. K. (1983). Multilocus genetic structure in natural populations of Escherichia coli. Proc Natl Acad Sci USA 80, 1751-1755.

60. Willems, A. \& Collins, M. D. (1993). Phylogenetic analysis of rhizobia and agrobacteria based on 16S rRNA gene sequence. Int $J$ Syst Bacteriol 43, 305-313.
61. Yanagi, M. \& Yamasato, K. (1993). Phylogenetic analysis of the family Rhizobiaceae and related bacteria by sequencing of 16S rRNA gene using PCR and DNA sequencer. FEMS Microbiol Lett 107, 115-120.

62. Young, J.P. W. \& Haukka, K. E. (1996). Diversity and phylogeny of rhizobia. New Phytol 133, 87-94. 